\title{
LINGVISTIČKA OBILJEŽJA NJEMAČKOG JEZIKA U KONTEKSTU PRAVA EUROPSKE UNIJE NA PRIMJERU AMSTERDAMSKOG UGOVORA
}

Sažetak: $\quad$ U ovome se radu istražuje njemački jezik pravne struke u okviru nadnacionalnoga prava Europske unije. U teorijskom se dijelu rada predstavljaju i analiziraju obilježja njemačkoga jezika prava na temelju prethodnih istraživanja njemačkoga jezika pravne struke. U empirijskom se dijelu rada istražuju lingvistička obilježja njemačkoga jezika na korpusu Amsterdamskog ugovora na temelju kategorizacije obilježja njemačkoga jezika pravne struke u sekundarnoj pravnolingvističkoj literaturi. Rezultati analize pokazat će koja su lingvistička obilježja karakterističnazaAmsterdamski ugovorkaojedanod osnivačkih ugovora Europske unije te razlikuju li se i u kojoj mjeri od onih utvrdenih u referentnoj literaturi o njemačkome jeziku pravne struke. Polazeći od činjenice da različiti pravni sustavi generiraju različite pravne pojmove i specifičnu pravnu terminologiju $i$ frazeologiju, polazna je hipoteza ovoga rada da će se i u Amsterdamskom ugovoru kao jednome od primarnih izvora prava Europske unije najveće razlike pokazati na području terminologije i frazeologije, tj. na leksičkoj i stilskoj razini.

Ključne riječi: $\quad$ pravo Europske unije, primarni izvori prava, lingvistička obilježja, njemački jezik, Amsterdamski ugovor

\section{UVODNE NAPOMENE}

U procesu su europskih integracija ne samo pravna pitanja, nego i pitanja vezana za jezik pravnih tekstova postala aktualnom temom kako pravnika tako i jezikoslovaca. Rasprave su vođene o ravnopravnosti jezika svih država članica o francuskom, engleskom i njemačkom

\footnotetext{
* Dr. sc. Ljubica Kordić, izvanredna profesorica, Pravni fakultet Sveučilišta Josipa Jurja Strossmayera u Osijeku, Stjepana Radića 13, 31000 Osijek. Adresa e-pošte: kljubica@pravos.hr. ORCID: http://orcid.org/0000-0002-2900-7906.

** Zdenka Barna, mag. inf. et comm. et mag. philol. germ., Ivana Gundulića 14, 31400 Đakovo, Adresa e-pošte: zbarna25@gmail. com. ORCID: http://orcid org/0000-0001-6511-068X.
} 
jeziku kao radnim jezicima institucija Europske unije, o politici prevođenja primarnih i sekundarnih izvora prava na jezike svih država članica, o usustavljenju i standardizaciji pravnih izraza u pravu Europske unije radi pojednostavnjenja procesa prevođenja u masivnom aparatu prevoditeljske službe Europske komisije, ${ }^{1}$ o specifičnim obilježjima pravne terminologije Europske unije u pojedinim jezicima itd. Nerijetko su ova pitanja dovodila do prijepora između pravnika i jezikoslovaca, a u području engleskoga jezika prava vrlo su aktualne rasprave o "pogrešnoj uporabi riječi” u pravnim tekstovima Europske unije. ${ }^{2} \mathrm{Da}$ je tomu tako i u njemačkom jeziku, svjedoče primjeri pogrešnog ili nedosljednog prijevoda, kao npr. prijevod termina Gesundheitswesen u nazivu dokumenta Grünbuch der Kommission (COM(2008) 725 endg.) über Arbeitskräfte des Gesundheitswesens in der EU, koji glasi Komisijina Zelena knjiga (COM(2008) 725 final) o radnoj snazi EU-a za zdravlje $e^{3}$ umjesto “(...) o zdravstvenim radnicima u EU-u”. U ovome se radu na primjeru teksta Amsterdamskog ugovora, jednoga od osnivačkih ugovora Europske unije, analiziraju lingvistička obilježja njemačkih pravnih tekstova u kontekstu prava Europske unije. S obzirom na ograničen korpus istraživanja u odnosu na konglomerat zakonskih tekstova primarnoga i sekundarnoga prava Unije, istraživanje prikazano u ovome radu ne može značajnije pridonijeti spoznajama o lingvističkim obilježjima pravnih tekstova EU-a u području njemačkog jezika, ali njegovi rezultati mogu biti indikativni i ukazati na opće lingvističke značajke ugovora EU-a, kao i na eventualne razlike u odnosu na dosadašnje spoznaje o obilježjima njemačkoga jezika prava. U uvodnom se dijelu rada definiraju cilj i hipoteza te korpus i metodologija istraživanja. U teorijskom dijelu rada autorice, referirajući se na dosadašnje relevantne spoznaje o lingvističkim obilježjima njemačkoga jezika prava, nude sustavan prikaz obilježja pravnih tekstova na tome jeziku na leksičkoj, morfosintaktičkoj i stilskoj razini te na razini tvorbe riječi. Glavni je dio rada posvećen istraživanju lingvističkih obilježja Amsterdamskog ugovora kao primjera primarnog prava EU-a. Analiza lingvističkih obilježja provodi se prema kategorizaciji obilježja iz teorijskog dijela rada kao referentnog kriterija analize. U diskusiji se raspravlja o sličnostima i razlikama u odnosu na dosadašnje spoznaje o lingvističkim obilježjima pravnih tekstova, dok se u zaključnom dijelu rada izvode zaključci o specifičnim lingvističkim obilježjima Amsterdamskog ugovora kao primjera pravnoga teksta u okviru primarnoga prava EU-a. Na kraju se ukazuje na ograničenja provedenog istraživanja i moguća otvorena pitanja za buduća istraživanja.

\section{CILJ I HIPOTEZA ISTRAŽIVANJA}

Cilj je ovoga rada istražiti lingvistička obilježja osnivačkog ugovora Europske unije na primjeru korpusa teksta Amsterdamskog ugovora na njemačkom jeziku kao jednoga od primarnih pravnih izvora Europske unije i utvrditi postoje li razlike u odnosu na obilježja karakteri-

1 Šarčević, S. (ur.), Legal Language in Action: Translation, Terminology, Drafting and Procedural Issues, Globus, Zagreb, 2009.; Trosborg, A., Translating Hybrid Political Texts. In: Trosborg, Anna (ed.), Text Typology and Translation, str. 145-158. John Benjamins, Amsterdam, Philadelphia, 1997.

2 Yankova, D., On Some Aspects of Prescriptive Legal Texts in Continental, Common Law and Supranational Jurisdictions, in: Sočanac, L., C. Goddard, L. Kremer (ur.) Curriculum, Multinlingualism and the Law. Language and Law - Studies in Legal Linguistics, str. 483.-495., Globus, Zagreb, 2008.; Gardner, J., Misused English words and expressions in EU publications. European Court of Auditors, 2016. 
stična za njemački jezik prava koja su u dosad objavljenim pravno-lingvističkim publikacijama razradili eminentni njemački i austrijski lingvisti (Günther: 1898., Busse: 1992., Weber: 1975., Hassemer: 1992., Sandrini: 1999., Kühn: 2001., Klein: 2001., Stolze: 2009., 2011., Felder: 2003.), ${ }^{4}$ a od hrvatskih germanista Petrović (2001.), ${ }^{5}$ Karabalić (2018.) ${ }^{6}$ i Kordić (2013., 2015.) $)^{7}$. S obzirom na to da svaki pravni sustav razvija svoje pravne institute, tijela, vrijednosti i načela funkcioniranja, koji onda generiraju i specifične pravne pojmove i odgovarajuću terminologiju i frazeologiju, ${ }^{8}$ polazna je hipoteza ovoga rada da će se i u tekstu Amsterdamskog ugovora kao jednoga od primarnih izvora prava Europske unije najveće razlike u odnosu na opća obilježja pravnih tekstova na njemačkom jeziku pokazati upravo na području terminologije i frazeologije, tj. na leksičkoj i stilskoj razini.

\section{KORPUS I METODOLOGIJA ISTRAŽIVANJA}

U radu se istražuju lingvistička obilježja teksta Amsterdamskog ugovora kao jednoga od primarnih izvora prava Europske unije. Iz toga se teksta kao korpusa istraživanja uz pomoć kompjutorske aplikacije find (F5) pretražuju i ekscerpiraju pravni izrazi jednostavnim strojnim prepoznavanjem naziva prema tvorbenim nastavcima, prema kojima su prethodno klasificirani u određene kategorije riječi - glagole, imenice, pridjeve i priloge. Prikupljeni se podatci i kvantitativno analiziraju s pomoću kompjutorskog alata MorphAdorner V2.0 dostupnog na mrežnoj platformi Sveučilišta NUIT (Northwestern University, Evanston, USA), kojim se utvrđuje ukupan broj pojavnica u korpusu te učestalost pojedinih pravnih termina. Na taj će se način prema kriteriju učestalosti pojavljivanja u korpusu Amsterdamskog ugovora utvrditi stručni termini karakteristični za ugovore EU-a, koji će se zatim kvalitativno analizirati na leksičkoj, morfosintaktičkoj razini te na razini tvorbe riječi i stilskoj razini. Rezultati analize termina, fraza i struktura koje se rabe u Amsterdamskom ugovoru uspoređuju se s relevantnim teorijskim spoznajama o obilježjima pravnih tekstova njemačkoga jezika koji su prezentirani u uvodnom dijelu rada.

4 Günther, L., Recht und Sprache. Ein Beitrag zum Thema vom Juristendeutsch, Karl Heymanns Verlag, Berlin, 1898.; Busse, D., Recht als Text. Linguistische Untersuchungen zur Arbeit mit Sprache in einer gesellschaftlichen Institution. Reihe Germanistische Linguistik, Tübingen, 1992.; Weber, S., Sprache und Recht, Universität Chemnitz, Chemnitz, 1975.; Hassemer, W., Richtiges Recht durch richtiges Sprechen, u: Grewendorf, G. (ur.), Rechtskultur als Sprachkultur - Zur forensischen Funktion der Sprachanalyse, Suhrkamp, Frankfurt am Main, 1992., str. 71.-92.; Sandrini, P., Translation zwischen Kultur und Kommunikation: der Sonderfall Recht, u: Sandrini, P. (ur.): Übersetzen von Rechtstexten - Fachkommunikation im Spannungsfeld zwischen Rechtsordnung und Sprache, Gunter Narr Verlag, Tübingen, 1999., str. 10.-45.; Klein, J., Parlamentarischer Diskurs als Schnittstelle zwischen politischer Allgemeinsprache und Rechtssprache, u: Haß-Zumkehr, U. (ur.), Sprache und Recht, Institut für Deutsche Sprache, W. de Gruyter, Berlin-New York, 2001., str. 163.-180.; Kühn, P., Juristische Fachtexte, u: Helbig et al. (ur.): Deutsch als Fremdsprache. Ein internationales Handbuch, W. de Gruyter, Berlin-New York, 2001, str. 582.-594.; Stolze, R., Fachübersetzen - Ein Lehrbuch für Theorie und Praxis, Frank \& Timme, Berlin, 2009.; Stolze, R., The Translator's Approach - Introduction to Translational Hermeneutics: Theory and Examples from Practice, Frank \& Timme, Berlin, 2011.; Felder, E., Juristische Textarbeit im Spiegel der Öffentlichkeit, Walter de Gruyter, Berlin-New York, 2003.

5 Petrović, V., Syntax des zusammengesetzten Satzes im Deutschen, Školska knjiga, Zagreb, 2001

6 Karabalić, V., Deutsche Fachsprachen. Ein Lehrbuch, Filozofski fakultet, Osijek, 2018.

7 Kordić, Lj., Kurzwortbildungen als Merkmal der deutschen Rechtssprache. Linguistica, 2013, 53 (2), str. 185.-197.; Kordić, Lj., Pravna lingvistika - sinergija jezika i prava, Pravni fakultet, Osijek, 2015.

8 Sandrini, P., op. cit. u bilj. 3; Šarčević, S., New Approach to Legal Translation, Kluwer Law International, The Hague-LondonBoston, 2000. 


\section{TEORIJSKA OSNOVA ISTRAŽIVANJA NA TEMELJU SEKUNDARNIH IZVORA}

\subsection{OPĆA OBILJEŽJA JEZIKA PRAVNE STRUKE}

Jezik prava jedan je od brojnih stručnih jezika koji služe kao sredstvo komunikacije u različitim profesionalnim područjima. Ipak, jezik pravne struke bitno se razlikuje od mnogih stručnih jezika: on je istodobno i sredstvo ostvarenja prava i dostojanstva svakoga čovjeka, ali i medij kojim se definiraju, prenose i tumače pravna pravila na kojima se temelji određena društvena zajednica. Ovim jezik prava predstavlja pomoćno sredstvo oblikovanja pravnoga i političkoga poretka svake države. Na posebno mjesto jezika u pravu te njegovu važnost za funkcioniranje pravnoga poretka jasno ukazuje Hassemer:

Zakoni, njihova konkretizacija u sudačkom pravu i pravnoj dogmatici, njihovo tumačenje i primjena u sudskim odlukama, kao i u kritici tih odluka - sve je to jezik. Gdje prestaje jezik počinje sila, koja se opet može izbjeći u onoj mjeri u kojoj djeluje jezik. ${ }^{9}$

Jezik je pravne struke, kako u povijesti tako i danas, zbog svoje kompleksnosti i apstraktnosti često nerazumljiv laicima kao adresatima. Opće je uvjerenje da su temeljna obilježja pravnoga teksta egzaktnost, preciznost, neutralnost i objektivnost. Zbog specifične komunikacijske i društvene funkcije zakonskih tekstova, prema Felderu ${ }^{10}$ osobitu pozornost treba posvetiti teškoćama u razumijevanju pravnih termina i jezika prava općenito. Haikke Mattila, jedan od prvih lingvista u svijetu koji je sustavno i dijakronijski proučavao jezik prava i kojemu zahvaljujemo prvo opsežno znanstveno djelo posvećeno pravnoj lingvistici, jasno je definirao obilježja tipična za jezik pravne struke, neovisno o jezičnom sustavu kojemu pripada. ${ }^{11}$ To su sljedeća obilježja: preciznost izričaja, zasićenost informacijama (redundantnost), neutralnost, sustavnost, strukturiranost i formalnost pravnih tekstova, učestalost skraćenica i akronima (osobito u nazivlju i strukturi zakona), kompleksnost rečenica i različitost jezičnih elemenata, arhaičnost i svečanost stila te pravilna i dosljedna uporaba pravnoga registra. Univerzalno obilježje koje prema Kordić12 u Mattilinoj taksonomiji nedostaje jesu izrazi vrijednosnoga karaktera u jeziku pravne struke koji sami po sebi imaju obilježja subjektivnosti (npr. u dobroj vjeri/im guten Glauben/in good faith; u najboljem interesu/im besten Interesse/in best interest, itd.) te višeznačnost stručnih termina. Prvi je primjer osobito zanimljiv jer je u suprotnosti s objektivnosti i neutralnosti pravnoga teksta i rezultat je povijesne povezanosti pisanoga prava s običajnim pravom. ${ }^{13}$ Ovakve primjere njemački lingvisti (Kühn, Stolze, Busse) ${ }^{14}$ nazivaju neodređenim ili nedovoljno definiranim izrazima subjektivnog karaktera, odnosno općenitim vrijednosnim izrazima. Sandrini ih u svojim radovima naziva i Generalklauseln oder Ermessen-

9 Hassemer, W., op. cit., u bilj. 3, str. 98. (S njemačkog jezika prevela Lj. Kordić.)

$10 \quad$ Felder, E., op. cit. $u$ bilj. 3.

11 Mattila, Heikki E. S., Comparative Legal Linguistics. Language of law, Latin and modern lingua franca, 2nd edition. Ashgate Publishing Ltd., 2006.

12 Kordić, Lj., op. cit. u bilj. 6.

13 Kordić, Lj., Elementi neformalnosti i poetičnosti u jeziku prava, u: Zbornik radova HDPL Prostor i vrijeme u jeziku: Jezik u prostoru i vremenu, HDPL i Filozofski fakultet Sveučilišta J. J. Strossmayera, Zagreb - Osijek, 2010., str. 175.-185. 
sbegriffe, ${ }^{15}$ dok ih u recentnijim radovima preciznije određuje kao neodređene pojmove koji nemaju precizno određene denotate. ${ }^{16}$ Stil jezika prava često se opisuje kao kondenzirani stil zasićen imeničkim frazama i sintagmama u višestruko složenim rečenicama koje je katkad teško razumjeti. Ovo je obilježje zbog specifične strukture rečenica u zakonskim tekstovima krajem 19. stoljeća Günther nazvao izlomljenim stilom/zerhackter Stil/.17

\subsection{OBILJEŽJA NA LEKSIČKO-SEMANTIČKOJ RAZINI I RAZINI TVORBE RIJEČI}

Na početku ovoga odjeljka treba naglasiti da je vrlo teško pouzdano razgraničiti pojedine razine jezične analize, budući da je, primjerice, pitanje složenica ujedno i morfološko, a potom i semantičko pitanje, tako da analiza na razini tvorbe riječi nužno sadrži i morfološke i semantičke elemente.

Obilježja koja je prije više od 130 godina uočio Günther razradili su i dopunili suvremeni predstavnici njemačke škole pravne lingvistike, osobito Busse, Kühn, Klein, Stolze i Sandrini. ${ }^{18}$ Na temelju njihovih spoznaja dolazimo do sljedeće taksonomije lingvističkih obilježja njemačkoga jezika prava na razini leksikologije i semantike: ${ }^{19}$

- uporaba stručnih izraza koji su personifikacija apstraktnih sadržaja: der Erblasser, der Beklagte (ostavitelj, tuženik)

- uporaba određenih pravnih izraza preuzetih iz općega jezika, npr. der Kauf (kupnja), der Tausch (razmjena), die Miete (najam), die Beleidigung (uvreda)

- uporaba apstraktnih izraza koji nose točno definirano pravno značenje, npr. das Eigentum (vlasništvo) i Besitz (posjed) koji znači stvarno raspolaganje nekom stvari ${ }^{20}$

- uporaba tuđica, uglavnom iz latinskoga i francuskoga jezika Kompetenz (nadležnost), Präsident (predsjednik), Jurist (pravnik), kao i adaptacija latinskih izraza, fraza i sentencija, npr.: de legel lata, mens rea, in flagranti

- uporaba tzv. vrijednosnih riječi (Wertwörter), poput pridjeva betrügerisch (lažno, prijevarom), gewissenlos (nesavjesno), te frazema Reinheit und Gesundheit des Geschlechtslebens (čistoća i zdravlje spolnoga života), im guten Glauben (u dobroj vjeri). Ovaj fenomen Kühn naziva "teškim riječima" (hard words) koje su u pravilu internacionalizmi: öffentliches Interesse; public interest (javni interes); bestes Interesse, best interest (najbolji interes,

15 Sandrini, P., op.cit. u bilj. 3, str. 80.-82.

16 Arntz, R.: Sandrini, P., Präzision versus Vagheit: Das Dilemma der Rechtssprache im Lichte von Rechtsvergleich und Sprachvergleich u: Bassey E. A. (ur): Indeterminacy in Terminology and LSP, John Benjamins Publishing Company, Amsterdam/Philadelphia, 2007., str. 135.-157.

17 Günther, L., op. cit. u bilj. 3.

18 Kordić, Lj., 2015., op. cit.u bilj. 6.

19 Ova je obilježja s povijesnog gledišta predstavila Lj. Kordić u radu iz 2008. (Kordić, Lj., Njemački jezik prava s povijesnog gledišta u: V. Karabalić - M. Omazić (ur.): Istraživanja, izazovi i promjene u teoriji i praksi prevođenja, Sveučilište J. J. Strossmayera i Filozofski fakultet, Osijek, 2008., str. 289.-303.). 
dobrobit $)^{21}$ itd., dok ga Stolze naziva "neodređenim pravnima izrazima" ili "izrazima bez preciznoga vrijednosnog određenja"22

- uporaba otvorenih pravnih izraza (obično ih zovemo stručnim terminima) npr. Zwangsvollstreckung (ovrha) i skrivenih pravnih izraza ${ }^{23}$ koji imaju različito značenje u općem jeziku i jeziku prava ili čak unutar pojedinih pravnih područja, kao npr. die Leistung izraz koji u općem jeziku ili u radnom pravu znači učinak, postignuće, uspjeh, ali u građanskom pravu, osobito obveznom pravu, nosi značenje činidba.

S obzirom na specifičan tvorbeni sustav njemačkoga jezika koji ujedno ima i morfološke implikacije, uočljiva su specifična obilježja karakteristična za jezik prava. Takvo je karakteristično obilježje a) učestala uporaba izvedenica i složenica b) uporaba složenica nastalih spajanjem polileksičkih pravnih fraza i izraza u jednu složenicu npr. Inkrafttreten (stupanje na snagu) ili izvedenicu, poput.: Zurhaftbringung (dovođenje u pritvor), Unbrauchbarmachung (činjenje neupotrebljivim). Tipično za njemački jezik prava je i c) kraćenje višečlanih složenica izostavljanjem jednoga dijela radi jezične ekonomije, što je osobito uočljivo u kaznenom pravu. Značenje termina poput Freiheitsstrafe, koji je nastao slaganjem izraza Freiheit (sloboda) i Strafe (kazna) te izostavljanjem središnjeg morfema Entzug (oduzimanje)/Freiheitsentzugsstrafe/ ili termina Familiendiebstahl nastalog slaganjem morfema Familie (obitelj) i Diebstahl (krađa) te izostavljanjem središnjeg morfema Mitglied (član) /Familienmitglieddiebstahl/ bez sumnje će razumjeti pravnik koji se bavi kaznenim pravom, ali ne i prevoditelj koji nije dovoljno upoznat s fenomenima pravne struke.

\subsection{OBILJEŽJA NA MORFOSINTAKTIČKOJ RAZINI}

Istraživanja njemačkog jezika prava na morfosintaktičkoj razini ukazuju na sljedeća karakteristična obilježja:

- gomilanje genitiva i participa, npr.: die irrige Einnahme der sachlichen Voraussetzungen eines anerkannten Rechtfertigungsgrundes = pogrešno shvaćanje stvarnih pretpostavki za priznavanje razloga opravdanosti (kaznenog djela)

- poimeničeni participi i pridjevi u apstraktnom značenju der Angeklagte, der Abgeordnete (optuženi, zastupnik)

- uporaba pridjeva s tvorbenim nastavcima -mäßig, npr. ordnungsmäßige Buchführung (uredno knjigovodstvo), -fähig, npr. rechtsfähige Person (pravno sposobna osoba), -bar, npr. strafbare Handlung (kažnjiva radnja) i -lich, kao natürliche Person (fizička osoba) te izvedenice iz tih pridjeva Prozessfähigkeit (procesna sposobnost), Gerichtsbarkeit (sudstvo), Verbindlichkeit (obvezatnost).

\footnotetext{
21 Kühn, P., op. cit. u bilj. 3, str. 586.

22 Stolze, R. 1999., op. cit. u bilj. 3.

23 Weber, op. cit. u bilj. 3.
} 
Günther ${ }^{24}$ ukazuje i na obilježje koje definira kao "nepoštovanje gramatičkih pravila”. Ovo obilježje Kühn stoljeće poslije ${ }^{25}$ ograničava samo na pogrešno atribuiranje, npr. dienende Grundstücke (doslovno: služeće zemljište) ili bewaffneter Diebstahl (naoružana krađa). Zanimljivo je da su hrvatski pravnici i jezikoslovci uveli kao ekvivalente nove izraze služno zemljište, odnosno oružana krađa, načinivši tako jasnu semantičku razliku između opisivanja živoga (osoba) i neživoga (protupravna radnja). Ovakve pojave Petrović ${ }^{26}$ naziva nelogičnim izrazima (Verstöße gegen die Logik).

U svojemu istraživanju provedenom jedno stoljeće poslije, Weber ${ }^{27}$ kao osobito učestale pojave na morfosintaktičkoj razini uočava:

- glagole u prezentu aktivnom i pasivnom

- modalne glagole können, müssen, sollen, dürfen, a za izricanje obveze ili nužnosti

- konstrukciju haben $+z u+$ Infinitiv, odnosno sein $+z u+$ Infinitiv te

- uporabu proširenih participa (glagolskih pridjeva trpnih i radnih) u atributnoj funkciji umjesto odnosnih rečenica.

Posljednje dvije strukture Weber naziva zgušnjavanjem jezika ("sprachliche Verdichtungen”), dok drugi autori ovaj fenomen stručnih jezika nazivaju "syntaktische Dichte und (...) inhaltliche Kondensierung" ${ }^{28}$ Karabalić ${ }^{29}$ pak kao pojavu uporabe kondenziranih izraza umjesto zavisnih rečenica ("Einsparung der Nebensätze") navodi i pridjevske izvedenice sa sufiksima -bar i -mäßig.

\subsection{OBILJEŽJA NA RAZINI STILA}

Na stilskoj razini, koja se nužno isprepleće s morfosintaktičkom, možemo govoriti o a) snažnoj zastupljenosti redundantnosti u pravnim tekstovima s jedne strane, ali i b) jezičnoj ekonomiji koja se postiže zgušnjavanjem i skraćivanjem izričaja. To se postiže, kako smo spomenuli, uporabom imeničkih sintagmi, pridjevskih fraza, strukture zu + Infinitiv te glagolskih pridjeva (participa) kao proširenih atributa umjesto zavisnih rečenica. Zbog ovih se obilježja stil jezika prava naziva imeničkim stilom. Njegova je svrha jezična ekonomija i sažimanje velikog broja podataka u što kraći tekst. Ova je stilska pojava u skladu s pravilima pravne nomotehnike, a osobito je naglašena u zakonskim tekstovima. Prema Susan Šarčevićc ${ }^{30}$ ovaj je fenomen posljedica tradicionalnoga nomotehničkog pravila utemeljenog na rimskom pravu prema kojemu je jedan zakonski članak ili barem stavak potrebno izraziti jednom rečenicom ("pravilo jedne rečenice”). Zbog kontradiktornosti stilske redundantnosti i “zgušnjavanja izraza”, Die-

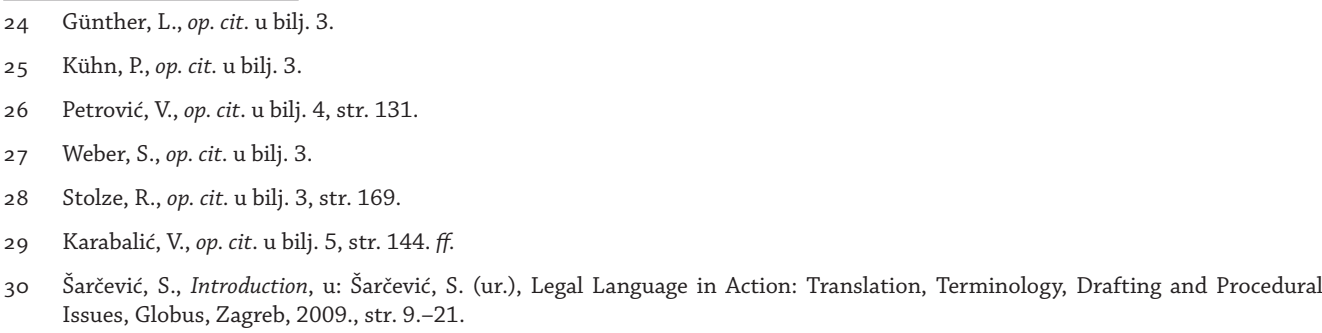


trich Busse ${ }^{31}$ govori o konfliktu kao ishodišnom karakteru prava i kao temeljnom obilježju njemačkoga jezika prava.

Metaforičnost pravnih frazema i izraza (c) još je jedna od kontradikcija pravnoga stila, koji je s jedne strane precizan i neutralan, a s druge ima elemente subjektivnosti i metafore. Subjektivnog su karaktera izrazi im guten Glauben (u dobroj vjeri) odnosno nach vernünftigem Ermessen (prema razumnoj procjeni), dok elemente metafore nalazimo u frazemima Rechte erwachsen und erlöschen (prava izrastaju i gase se), in Kraft treten (stupiti na snagu), Maßnahmen treffen (donijeti mjere) itd. Posljednja dva primjera ukazuju i na učestalu uporabu funkcionalnih glagola koji su izgubili svoje izvorno značenje te izrazu u kojemu se javljaju daju metaforični karakter. U pravnim sintagmama s funkcionalnim glagolima (Funktionsverbgefüge) učestalo se javljaju glagoli treffen, nehmen, stellen.

U sljedećem se poglavlju istražuje u kojoj su mjeri navedena obilježja zastupljena u Amsterdamskom ugovoru kao reprezentativnom tekstu iz područja prava EU-a.

\section{ISTRAŽIVANJE LINGVISTIČKIH OBILJEŽJA AMSTERDAMSKOG UGOVORA KAO PRAVNOGA TEKSTA EU-a}

Amsterdamski ugovor (pod punim nazivom Vertrag von Amsterdam zur Änderung des Vertrags über die Europäische Union, der Verträge zur Gründung der Europäischen Gemeinschaften sowie einiger damit zusammenhängender Rechtsakte) stupio je na snagu 1. svibnja 1999. i predstavlja treći skup opsežnih izmjena i dopuna Ugovora iz Maastrichta i osnivačkih ugovora Europske zajednice. Cilj je ovoga ugovora jačanje demokratičnosti funkcioniranja EU-a te sigurnosti i prava na području unutarnje politike i pravosuđa, kao i uvođenje značajnih institucionalnih reformi. Te su reforme trebale pridonijeti definiranju EU-a kao zajednice europskih građana, funkcionalne i spremne za primanje novih članica, a slijedom toga i za širenje europskoga tržišta rada, poticanje slobode kretanja i snažniju politiku zapošljavanja u EU-a. Njemačka verzija Amsterdamskog ugovora, koji je izvorno sastavljen na tri radna jezika EU-a - engleskom, francuskom i njemačkom - predstavlja korpus istraživanja ovoga rada i obuhvaća ukupno 148 stranica pravnoga teksta, koji se sastoji od 15 članaka, 13 protokola i 59 izjava. Kako je riječ o izvornome zakonskom tekstu iz opusa primarnih pravnih izvora Europske unije, on se može smatrati pouzdanom i relevantnom osnovom za lingvističko istraživanje koje je u fokusu ovoga rada. Mjereno kompjutorskim alatom MorphAdorner, cjelokupni tekst Amsterdamskog ugovora obuhvaća 1771 rečenicu i 52.190 tokena (pojavnica).

\subsection{OBILJEŽJA NA LEKSIČKO-SEMANTIČKOJ RAZINI I RAZINI TVORBE RIJEČI}

I ovdje treba naglasiti da ova razina analize nužno uključuje i morfosintaktičke elemente, budući da promatramo semantičku razinu pojavnica u kontekstu pravnoga teksta. U tekstu uo- 
čavamo brojne primjere složenica kao otvorenih i kao skrivenih pravnih izraza. Otvorene pravne izraze ilustriraju sljedeći primjeri: Beschlussfassung (donošenje odluke), Mindeststimmenzahl (minimalni broj glasova), Bruttosozialprodukt (bruto društveni proizvod). Kao ilustrativne primjere za skrivene pravne izraze možemo navesti složenicu das Haushaltsverfahren (postupak donošenja proračuna) i izvedenicu die Leistung. Prvi je primjer višeznačnog karaktera jer se odredbenica (Bestimmungswort) Haushalt može protumačiti i u njezinu značenju u općem jeziku (kućanstvo), dok u pravnom kontekstu ista imenica znači proračun. Terminologizacijom je od općejezičnog izraza nastao stručni izraz koji je laiku nejasan. Termin die Leistung (učinak, postignuće, radnja, činidba) javlja se i samostalno i kao određenica (Grundwort) unutar složenice, npr. Gewährleistung, a njezino je značenje u pravilu uvjetovano pravnim kontekstom u kojemu se rabi. U istraženom tekstu među stručnim izrazima dominiraju složenice. Nešto su manjim intenzitetom zastupljene izvedenice, a vrlo rijetko jednostavne riječi (Simplizia), poput primjera das Recht, der Krieg, $\operatorname{der} A k t$. Brojni su primjeri složenica čije su odredbenice različite vrste riječi - najčešće imenice i pridjevi: Unionsbürgerschaft (građanstvo Unije), Bürgerrechte (prava građana u kontekstu građanstva EU-a), Beschäftigungspolitik (politika zapošljavanja), Krisenbewältigung (prevladavanje krize), Binnengrenzen (unutarnje granice), Grundrecht (temeljno pravo), Außenpolitik (vanjska politika). Većina su ovih složenica apstraktnog karaktera i kao takve pridonose složenosti teksta. Apstraktnog su karaktera i mnoge izvedenice, osobito one sa sufiksima -heit, -keit, -ung, -ie, -tät, npr. Freiheit (sloboda), Sicherheit (sigurnost), Entwicklung (razvoj), Demokratie, Identität. U korpusu nalazimo nekoliko višečlanih složenica nastalih srastanjem višečlanog izraza u jednu riječ. Najučestalija višečlana složenica je imenica Inkrafttreten (stupanje na snagu) koja se javlja 43 puta u istraženom korpusu (nach Inkrafttreten des Vertrags von Amsterdam; vom Zeitpunkt des Inkraftretens des Vertrags von Amsterdam).

Nalazimo i nekoliko primjera poimeničenih participa apstraktnoga značenja koji personificiraju osobe, npr. der Bevollmächtigte (opunomoćenik), der Angehörige (pripadnik), a koji prema tvorbi mogu biti i složenice s pridjevom ili imenicom kao lijevom konstituentom: der Sonderbeauftragte (posebno ovlaštena osoba), der Staatsangehörige (državljanin). Posljednja dva primjera učestalo se javljaju u korpusu (potonji 34 puta) i semantički su usko vezani za pravna pitanja Europske unije kao međunarodne zajednice država.

U leksička obilježja njemački i austrijski lingvisti (primjerice R. Stolze te P. Sandrini) ubrajaju i vrijednosne riječi čiji je sadržaj semantički neprecizan. Primjeri pronađeni u ovome korpusu semantički bez dvojbe pripadaju pravu EU-a: gemeinsame Werte (zajedničke vrijednosti), Unversehrtheit der Union (nepovredivost Unije), internationale Sicherheit (međunarodna sigurnost), Stärkung der Demokratie (jačanje demokracije), gemeinschaftliche Solidarität (solidarnost unutar Europske zajednice) itd.

U tekstu se često javljaju i tuđice, najčešće iz grčkoga, latinskoga i francuskoga jezika, kao npr. Charta, Demokratie, Allianz, Kommitee, Niveau. Sporadično se javljaju i kratice za stručne termine političke provenijencije, npr. EU, WWU (Wirtschafts- und Währungsunion - Gospodarska i monetarna unija), WEU (die Westeuropäische Union) i NATO. 


\subsection{MORFOSINTAKTIČKA OBILJEŽJA}

U morfosintaktička obilježja jezika pravne struke ubrajamo, među ostalim, i učestalu uporabu imeničkih frazema ili sintagmi. Amsterdamski ugovor obiluje ovakvim izrazima, a izdvajamo samo neke: organisierte Kriminalität (organizirani kriminal), öffentliche Ordnung (javni poredak), gemeinschaftliche Rechtsvorschriften (pravni propisi EU-a), außerordentliche Maßnahmen (izvanredne mjere), einheitliche Währung (jedinstvena valuta), nachhaltige Entwicklung (održivi razvoj).

Pridjevi su u jeziku prava često prema svojoj tvorbenoj strukturi tipizirani, pa su dosadašnja istraživanja njemačkoga jezika prava pokazala učestalost pridjeva i priloga s tvorbenim sufiksima -lich, -bar, -ig, -fähig, -mäßig, -seits, -seitig. Prilozi i pridjevi sa sufiksom -bar koji su snažno zastupljeni u korpusu (83 pojavnice) jesu unmittelbar (neposredan), vereinbar (sukladan), verfügbar (dostupan, na raspolaganju), anwendbar (primjenjiv), annehmbar (prihvatljiv). Učestalo se javljaju pridjevi i prilozi sa sufiksom -mäßig (23 pojavnice): od općejezičnih regelmäßig, mengenmäßig, planmäßig, zweckmäßig (redovito, masovno, planski, svrhovito/ciljano), do usko pravnih izraza rechtmäßig i verwaltungsmäßig (pravno/sukladno pravnim propisima; upravno/ sukladno upravnim propisima). Potrebno je spomenuti da se ovi pridjevi i/ili prilozi javljaju i kao tvorbena osnova imenica Rechtmäßigkeit, Verhältnismäßigkeit, Ordnungsmäßigkeit (ukupno 41 primjer u korpusu). Za razumijevanje pravnih izraza iznimno je važno koji se pridjev pridružuje određenom terminu, jer se na taj način izbjegava višeznačnost, npr. organisatorische Leistung. Radi sažimanja iskaza učestalo se javljaju prilozi unbeschadet $i$ erforderlichenfalls koji su tipični za zakonske tekstove (prvi se javlja 29 puta, a drugi 12 puta).

$\mathrm{U}$ istraženom korpusu dominiraju imeničke sintagme i frazemi s pridjevima sa sufiksom -lich (ukupno 301 primjer). Osim pridjeva koji se semantički mogu svrstati u opći jezik svakodnevne komunikacije poput möglich (moguć), üblich (uobičajen), unterschiedlich (različit) vrlo su intenzivno zastupljeni pridjevi pravnoga karaktera, najčešće u kolokaciji s pripadajućim imenicama: sachliche Änderung (stvarna/bitna izmjena), amtliche Veröffentlichung (službena objava), schritfliche Erklärungen (pisano očitovanje), erforderliche Entscheidungen (potrebne odluke), verfassungsrechtliche Vorschriften (ustavnopravni propisi) itd. Ono što osobito upada u oči u analizi ovoga zakonskog teksta jest činjenica da su pridjevi na -lich većinom semantički usko vezani za pravni sustav Europske unije i relevantna pravna pitanja. Tako kao jedan od najučestalijih pridjeva u korpusu susrećemo gemeinschaftlich. Ovaj je pridjev teško prevesti jer je izveden iz imenice Gemeinschaft, pri čemu se misli na Europäische Gemeinschaften (Europske zajednice), kako je glasio naziv Europske unije do 1997. godine, a u pravnim tekstovima njemačkoga nacionalnog prava nije se javljao, bar ne u istome semantičkom kontekstu. Sintagme poput gemeinschaftliche Rechtsordnung, gemeinschaftliche Rechtsvorschrriften, gemeinschaftlicher Besitzstand, gemeinschaftliches Kontrollverfahren (pravni poredak Zajednice, pravni propisi Zajednice, stečevina Zajednice, postupak nadzora Zajednice) često se rabe u korpusu, i u svima se pridjev odnosi na Europsku zajednicu odnosno Europsku uniju, ali se radi jezične ekonomije rabi pridjev izveden iz staroga naziva Europäische Gemeinschaften, prije nego što je Ugovorom iz Maastrichta izmijenjen u Europska unija (14 različitih primjera). Još su intenzivnije zastupljene imeničke sintagme i frazemi s pridjevom einzelstaatlich, koji je nastao slaganjem pridjeva einzeln = pojedini i imenice Staat= država (ukupno 32 primjera), u značenju "koji se odnosi na pojedinu državu članicu”, a najčešće se prevodi kao "nacionalni”": einzelstaatliche Par- 
lamente, einzelstaatliche Politik, einzelstaatliche Stellungnahmen (ovdje: pojedinačna stajališta država članica), einzelstaatliche Bestimmungen (nacionalne zakonske odredbe), einzelstaatliche Dienststellen (nacionalne službe), einzelstaatliche Gepflogenheiten (nacionalne prakse), einzelstaatliche Rechnungsprüfungsorgane (nacionalni financijski nadzor). Treći je prema učestalosti u korpusu pridjev innerstaatlich, nastao slaganjem pridjeva inner i imenice Staat. Budući da oba pridjeva (einzelstaatlich, innerstaatlich) stoje u kolokacijskom odnosu s istim imenicama (innerstaatliches Recht, innerstaatliche Stellen, innerstaatliche Bestimmungen) i zahvaćaju isto semantičko polje, mogu se smatrati sinonimima (ukupno 10 primjera). Od ostalih pridjevskih složenica susrećemo sachdienlich (relevantan) i zweckdienlich (odgovarajući, svrhovit): sachdienliche Informationen, zweckdienliche Maßnahmen, zweckdienliche Verordnungen. Ovo navodi na zaključak da su složeni pridjevi, koji se u njemačkoj pravno-lingvističkoj teoriji ne navode kao karakteristično obilježje, jedan od čimbenika imeničkog stila i “zgušnjavanja” izričaja u osnivačkim ugovorima EU-a. Istraživanje većega i reprezentativnijeg korpusa, koji bi uključivao različite vrste pravnih tekstova Europske unije, pokazao bi jesu li ta obilježja karakteristična za jezik prava EU-a općenito i odražavaju li nove pravne fenomene i odnose u složenoj zajednici naroda i kultura kakva je Europska unija.

U korpusu Amsterdamskog ugovora slabo su zastupljeni pridjevi sa sufiksom -fähig - tek dva primjera s istim pridjevom: leistungsfähige Arbeitskräfte, leistungsfähige Finanzinfrastruktur (učinkovita radna snaga/financijska infrastruktura). Sukladno tomu i izvedenice sa sufiksom -fähigkeit nalazimo samo u dva primjera: Anpassungsfähigkeit (sposobnost prilagodbe) i Wettbewerbfähigkeit (konkurentnost). Još se rjeđe javljaju pridjevi sa sufiksom -seitig. Nailazimo na samo dva primjera s pridjevom gegenseitig: gegenseitige Solidarität (uzajamna solidarnost) gegenseitige Unterrichtung und Abstimmung (međusobno informiranje i glasovanje). Priloge sa sufiksom -seits ne nalazimo u korpusu.

Analizom teksta Amsterdamskog ugovora uočena su i dva primjera pogrešnoga atribuiranja ili uporabe nelogičnih izraza - obilježja koje je još 1898. godine navedeno kao karakteristično obilježje jezika prava (Günther, 1898.), ali i tada se taj fenomen uočavao sporadično. Da je taj fenomen i danas prisutan u zakonodavstvu Europske unije, potvrđuje sintagma einheitliche Visumgestaltung, koja zapravo ne znači zajednički izgled/dizajn vize, nego izgled zajedničke vize. $\mathrm{Na}$ ovaj zaključak navodi učestala uporaba sintagme einheitliches Visum koja se u tekstu rabi u značenju zajednička viza, pa je i u primjeru einheitliche Visumgestaltung riječ o atribuiranju prvoga dijela složenice umjesto drugoga kao temeljne riječi. Za ilustraciju nedovoljno jasnoga atribuiranja možemo navesti i učestale sintagme s pridjevom gemeinschaftlich, koji se ne odnosi na bilo koju zajednicu, kako bi se moglo činiti neupućenom čitatelju, nego na naziv Europska zajednica - Europäische Gemeinschaften, što je bivši naziv Europske unije. Zbog svoje karakteristične etimologije, pridjev gemeinschaftlich na hrvatski se jezik prevodi polileksičkim izrazom, npr. gemeinschaftliche Rechtsordnung - pravni poredak Europske zajednice).

U teorijskom smo dijelu ovoga rada vidjeli da u morfosintaktička obilježja njemačkoga jezika prava ubrajamo i uporabu pasiva i prezenta aktivnog te modalnih glagola können, müssen, sollen, dürfen (moći, morati, trebati, smjeti), a da se radi jezične ekonomije i sažetijeg izričaja umjesto zavisnih rečenica rabe konstrukcije $z u+$ Infinitiv te prošireni particip (glagolski pridjev) u službi atributa. Da su ova obilježja snažno prezentna u Amsterdamskom ugovoru ilustriraju sljedeći primjeri: 
Die Ermächtigung nach Absatz 1 wird vom Rat, der mit qualifizierter Mehrheit beschließt, auf Antrag der betreffenden Mitgliedstaaten erteilt, nachdem die Kommission ersucht wurde, hierzu Stellung zu nehmen... (str. 21.).

Die Mitgliedstaaten, die beabsichtigen, untereinander eine verstärkte Zusammenarbeit zu begründen, könnenvorbehaltlich der Artikel K.15 und K.16 ermächtigt werden, die in den Verträgen vorgesehenen Organe, Verfahren und Mechanismen in Anspruch zu nehmen, sofern die beabsichtigte Zusammenarbeit (...). (str. 21.)

Trifft die Kommission innerhalb dieses Zeitraums keine Entscheidung, so gelten die in den Absätzen 4 und 5 genannten einzelstaatlichen Bestimmungen als gebilligt. (str. 32.)

Kao karakteristične primjere proširenih glagolskih pridjeva (participa) u službi atributa koji se često rabe $\mathrm{u}$ istraženom korpusu umjesto zavisnih rečenica, možemo navesti i sljedeće primjere: das in diesem Absatz vorgesehene Gerichtsverfahren (sudski postupak predviđen u ovom stavku); in den in Artikel K.1 genannten Bereichen (u područjima navedenim u čl. K 1.); die im Rahmen dieses Titels angenommenen gemeinsamen Standpunkte (zajednička stajališta prihvaćena u okviru ovog poglavlja). Oni ukazuju na snažnu zastupljenost fenomena kondenziranja izraza i imeničkog stila radi ekonomičnosti i sažetosti jezičnoga iskaza.

\subsection{OBILJEŽJA NA STILSKOJ RAZINI}

Kako ilustriraju primjeri navedeni u prethodnom poglavlju, analiza na morfosintaktičkoj razini nužno uključuje i stilsku razinu. Imenički stil karakterističan je za zakonske tekstove, u kojima se nastoji što veći broj propisa izraziti zgusnutim rečeničnim iskazom. Bilo je očekivano da je zastupljen i u Amsterdamskom ugovoru, osobito zbog činjenice da i novija istraživanja ukazuju kako imenički stil dominira zakonodavnim tekstovima Europske unije. ${ }^{32} \mathrm{U}$ poglavlju posvećenom morfosintaktičkoj analizi prikazane su strukture koje se rabe umjesto zavisnih rečenica: imenički frazemi i sintagme, prijedložne fraze te skupine riječi s glagolskim oblicima u atributnoj funkciji (tj. prošireni participi u službi atributa), ali i složeni pridjevi te pridjevske izvedenice sa sufiksima -lich, -bar, i -mäßig.

Imeničke sintagme čije su konstituente u kolokacijskom odnosu također su obilježje imeničkog stila i učestalo se rabe u korpusu: natürliche Personen (fizičke osobe), juristische Personen (pravne osobe); qualifizierte Mehrheit (kvalificirana većina), Zusammenarbeit begründen (pokrenuti suradnju), Stellung nehmen (zauzeti stajalište), Entscheidung treffen (donijeti odluku).

Posljednja se dva primjera mogu definirati i kao sintagme s frazeološkim ili funkcionalnim glagolima (Funktionsverbgefüge) koji su s vremenom izgubili svoje izvorno značenje te su metaforičnog karaktera. Kao najčešći funkcionalni glagoli u općem se jeziku navode stellen, nehmen, treffen. U korpusu se glagol stellen javlja samo u dvije sintagme: Frage stellen, zur Verfügung stellen (hrv. postaviti pitanje, staviti na raspolaganje) - ukupno 12 primjera. Nešto je intenzivnije zastupljen glagol treffen, najčešće u frazi Maßnahmen treffen - donijeti mjere (17 primjera) te Schutzmaßnahmen treffen - donijeti zaštitne mjere (4), zatim Regelungen treffen - donijeti 
propise (5), Entscheidung treffen - donijeti odluku (5) te Feststellung treffen - utvrditi (2), što čini ukupno 33 primjera s funkcionalnim glagolom treffen. Glagol nehmen uglavnom se javlja u frazama koje uočavamo i u općem jeziku: in Anspruch nehmen (15 primjera), in Bezug nehmen (4) - obje u značenju uzeti u obzir - te zur Kenntnis nehmen - uzeti na znanje (7 primjera), dok su s po jednim primjerom zastupljeni izrazi in Angriff nehmen te in Aussicht nehmen (ukupno 28 primjera). Zanimljivo je da se u korpusu javljaju drugi funkcionalni glagoli koji se zbog učestalosti svoga pojavljivanja mogu svrstati u funkcionalne glagole karakteristične za pravo Europske unije, a najčešće se javljaju u kolokacijskoj vezi s određenim imenicama. To se osobito odnosi na glagol annehmen (prihvatiti), koji se javlja u kolokaciji sa sljedećim imenicama: Beschluss (odluku) - 15 primjera, i Maßnahmen (mjere) - 9 primjera. Po dva su puta zastupljene sintagme s imenicama Erklärungen (izjavu, očitovanje), Entscheidung (odluku), Bestimmungen (odredbe), Richtlinien (direktive), a tri puta se u tekstu javlja dvojni frazem gemeinsame Aktionen und Standpunkte annehmen (prihvatiti zajedničke akcije i stajališta), što iznosi ukupno 35 primjera s funkcionalnim glagolom annehmen. Nešto su slabije zastupljeni frazemi s glagolom vornehmen: Änderungen vornehmen (poduzeti promjene), Aufhebungen vornehmen (poduzeti/ pokrenuti ukidanja) te Ermittlungen vornehmen (poduzeti/pokrenuti istragu) i militärische Planungen vornehmen (pokrenuti/započeti vojne planove). Može se zaključiti da se osim frazema s funkcionalnim glagolima treffen i nehmen, koji se u nekim radovima ističu kao karakteristični za jezik prava, ${ }^{33}$ u Amsterdamskom ugovoru kao primjeru primarnoga prava EU-a javljaju funkcionalni glagoli annehmen (ukupno 35 primjera) i vornehmen (zastupljen sa 17 primjera).

Karakteristika imeničkog stila jesu i imeničke sintagme s genitivnim atributom koje su snažno zastupljene u korpusu: Schutz der Umwelt und Arbeitsumwelt (zaštita okoliša i radnog okoliša); der Erlass der Harmonisierungsmaßnahme (donošenje harmonizacijskih mjera), die Vertreter der Regierungen der Mitgliedstaaten (predstavnici vlada država članica).

I velik broj prijedložnih frazema koje susrećemo u korpusu imeničkog su karaktera. Iako su neki od njih učestala pojava i u općem jeziku, poput in Bezug auf (s obzirom na), im Auftrag von (po nalogu), svi su semantički smješteni u domenu prava EU-a i sadrže postmodifikaciju u obliku genitivnog atributa: zu Lasten des Haushalts der Europäischen Gemeinschaften (na teret proračuna europskih zajednica), im Rahmen der jeweiligen Befugnisse von innerstaatlichen Organen (u okviru nadležnosti nacionalnih tijela); im Sinne des Vertrags (u smislu ugovora), nach Maßgabe dieses Vertrags (u skladu s ovim ugovorom). Pojavnost ovih struktura nije bilo moguće kvantitativno iskazati zbog različitosti leksičkih jedinica od kojih su nastale.

I dvojni frazemi koje čine dvije imenice ili dva pridjeva povezana veznicima und ili oder također su obilježje imeničkoga stila jezika pravne struke, ne samo u kontinentalno-europskom nego i u anglosaksonskom krugu. Primjeri dvojnih pravnih frazema pronađeni u našemu korpusu impliciraju da je uporaba pravnih frazema i sintagmi semantički uvjetovana pravnim područjem na koje se odnose. Kao potvrdu ove tvrdnje, u korpusu nailazimo na ove dvojne frazeme: Rechtsmäßigkeit und Ordnungsmäßigkeit (usklađenost sa zakonima i propisima), Protokolle und Rechtsakte (protokoli i pravni akti), Demokratie und Recht (demokracija i pravo), Subsidiarität und Verhältnismäßigkeit (subsidijarnost i proporcionalnost), Verhütung und Bekämpfung (sprečavanje i suzbijanje). O frazemskome karakteru ovih izraza svjedoči činje-

33 Usp. Kordić, Lj.; Marušić, B., Funktionsverbgefüge (FVG) als Merkmal der deutschen Rechts-und Verwaltungssprache. Comparative Legilinguistics, vol. 29/2017., str. 10.-30. 
nica da se $\mathrm{u}$ istom kolokacijskom odnosu pojavljuju više puta u tekstu. Veoma su često dvojni frazemi prošireni genitivnim atributima: Integrität und Kohärenz der gemeinschaftlichen Rechtsordnung (integritet i cjelovitost pravnog poretka Zajednice), Wettbewerbsfähigkeit und Konvergenz der Wirtschaftsleistung (konkurentnost i konvergencija gospodarstva), Ausbildung und Anpassungsfähigkeit der Arbeitnehmer (obrazovanje i sposobnost prilagodbe radnika). Snažno su zastupljeni i pridjevski dvojni frazemi: natürliche und juristische Personen (fizičke i pravne osobe), polizeiliche und justitielle Zusammenarbeit (suradnja u području pravosuđa i unutarnjih poslova); gerichtliche und außergerichtliche Schriftstücke/Entscheidungen (sudski i izvansudski spisi/odluke), offentliche oder private Interessen (privatni ili javni interesi), der institutionelle und rechtliche Rahmen (pravni i institucionalni okvir).

O zastupljenosti imeničkog stila u Amsterdamskom ugovoru kao primjeru osnivačkih ugovora EU-a svjedoči sljedeća rečenica:

Der Rat setzt nach Anhörung des Europäischen Parlaments einen Beschäftigungsausschuss mit beratender Funktion zur Förderung der Koordinierung der Beschäftigungs- und Arbeitsmarktpolitik der Mitgliedstaaten ein (str. 34.). U tom je smislu ilustrativan i puni naziv ovoga dokumenta Europske unije: Vertrag von Amsterdam zur Änderung des Vertragsüber die Europäische Union, der Verträge zur Gründung der Europäischen Gemeinschaften sowie einiger damit zusammenhängender Rechtsakte.

\section{DISKUSIJA REZULTATA}

U teorijskom smo dijelu ovoga rada naveli i analizirali karakteristična obilježja njemačkoga jezika pravne struke - kako ona koja je još krajem 19. stoljeća uočio Austrijanac Günther (1898.), tako i ona o kojima su stoljeće poslije raspravljali njemački i austrijski jezikoslovci koji se bave pravnom lingvistikom i pravnim prevođenjem. U empirijskom smo dijelu rada istražili jesu li i u kojoj mjeri obilježja koja su utvrđena kao karakteristična za njemački jezik u dosad objavljenim pravno-lingvističkim publikacijama zastupljena u korpusu teksta Amsterdamskog ugovora i postoje li razlike među njima. Analiza teksta na razini leksika, koja nužno uključuje i razinu semantike, pokazala je da se standardna obilježja njemačkih pravnih tekstova javljaju i u istraženom korpusu: otvoreni i skriveni pravni termini, višeznačnost izraza, pravni termini apstraktnoga karaktera, posuđenice iz latinskoga, francuskoga i (rjeđe) engleskoga jezika, ali i vrijednosni izrazi bez preciznoga semantičkog određenja. Ono što je karakteristično za primjere pronađene u našemu korpusu jest njihova semantička realizacija, koja je u pravilu u domeni prava EU-a, kao primjerice apstraktni vrijednosni izrazi: gemeinsame Werte, Unversehrtheit der Union, Wahrung der internationalen Sicherheit. Isto se odnosi i na kratice koje također susrećemo u korpusu, a koje se odnose na nazivlje institucija, organizacija i tijela EU-a.

I morfosintaktička analiza ukazuje da se u jeziku Amsterdamskog ugovora kao primjeru primarnoga prava EU-a javljaju mnoge strukture karakteristične za pravne tekstove općenito: od uporabe glagolskih vremena i oblika (pasiv, prezent aktivni, modalni glagoli, konstrukcije $z u+$ Infinitiv) do učestalih tvorbenih oblika pridjeva i imenica u specifičnim sintagmatskim ili kolokacijskim odnosima. Kao i u jeziku nacionalnog prava, i ovdje se učestalo javljaju pridjevi sa sufiksima -lich, -bar, -mäßig, ali su slabo zastupljeni oni sa sufiksima -fähig $i$-seitig. Karakte- 
ristična je za ugovore u pravu EU-a i česta uporaba izvedenih i složenih pridjeva koji svojom semantičkom realizacijom pripadaju pravu EU-a (gemeinschaftlich, einzelstaatlich, innerstaatlich). Uporaba ovakvih složenih pridjeva koji su u pravilu u kolokacijskoj vezi s jednom ili više imenica u službi je komprimiranja pravnoga izričaja (Verdichtung des Ausdrucks), što je prije više od jednoga stoljeća uočeno kao obilježje pravnoga stila. Također, iako se na prvi pogled čini da je fenomen pogrešnoga ili nelogičnoga atribuiranja potisnut iz suvremenoga njemačkog jezika prava, i u Amsterdamskom ugovoru nalazimo primjer gemeinsame Visumgestaltung te brojne primjere kolokacija s pridjevom gemeinschaftlich koji u istraženom korpusu semantički isključivo pripada domeni prava EU-a.

Usporedbom stilskih obilježja dolazimo do zaključka da su obilježja karakteristična za njemački jezik prava općenito u velikoj mjeri zastupljena i u konkretnome tekstu ugovora EU-a. Osobito je snažno zastupljen imenički stil izražen eliptičnim rečenicama i brojnim imeničkim sintagmama i frazemima. Znakovito je da se osim funkcionalnih glagola koji se u teorijskom dijelu ističu kao tipični za jezik prava (treffen i nehmen) u našemu korpusu javljaju i sintagme s funkcionalnim glagolima annehmen i vornehmen. Učestalost njihova pojavljivanja u sintagmama vezanim za proceduralna pitanja EU-a ukazuje na njihovu konceptualnu pripadnost pravu EU-a: Beschluss annehmen, Maßnahmen annehmen, Entscheidung annehmen, Richtlinie annehmen, Änderungen vornehmen, Aufhebungen vornehmen. Razlika između frazeologije njemačkoga nacionalnog prava i one prava EU-a osobito dolazi do izražaja u fenomenu dvojnih frazema. Nijedan od primjera koji se navode kao karakteristični za njemački jezik prava Njemačke i Austrije ne nalazimo u korpusu Amsterdamskog ugovora. U njemu su snažno zastupljeni frazemi koji pripadaju terminologiji Europske unije (gegenseitige Unterrichtung und Abstimmung zwischen Mitgliedstaaten; Integrität und Kohärenz der gemeinschaftlichen Rechtsordnung, Wettbewerbsfähigkeit und Konvergenz). Ista je semantička domena prepoznatljiva i u imeničkim frazama s atributom u genitivu (der Erlass der Harmonisierungsmaßnahmen, die Vertreter der Regierungen der Mitgliedstaaten) i prijedložnim frazama (im Sinne des Vertrags, nach Maßgabe des Vertrags, zu Lasten des Haushalts der Europäischen Gemeinschaften).

\section{ZAKLJUČNA RAZMATRANJA}

Na temelju navedenih rezultata možemo ustvrditi da se najveće razlike između obilježja utvrđenih u sekundarnoj pravno-lingvističkoj literaturi i onih u Amsterdamskom ugovoru uočavaju na razini pravne terminologije i frazeologije. Razlike su uočljivije na leksičko-semantičkoj i stilskoj te na morfosintaktičkoj razini. Tako možemo govoriti o specifičnim pravnim terminima EU-a, o sintagmama s funkcionalnim glagolima tipičnim za ugovore u kontekstu prava EU-a, karakterističnim imeničkim sintagmama i kolokacijama, prijedložnim frazama i dvojnim frazemima koji su prepoznatljivi kao izrazi imanentni tekstovima ugovora u primarnom pravu Europske unije. Dublji uzrok ovakvoga rezultata leži u činjenici da svaki pravni sustav, pa tako i supranacionalni sustav prava EU-a, generiraju različitu pravnu terminologiju i frazeologiju, što potvrđuje i polaznu hipotezu ovoga rada. U zaključku je svakako potrebno napomenuti da je istraživanje provedeno na uzorku Amsterdamskog ugovora kao primjeru primarnoga prava, pa se i izneseni zaključci odnose isključivo na taj konkretni dokument, ali mogu biti indikativni za ugovore kao tekstnu vrstu u kontekstu prava EU-a. Sukladno tomu, 
neki od glagola spomenutih u analizi karakteristični su za ugovor kao primarni pravni izvor EU-a te se ne može sa sigurnošću tvrditi da su podjednako učestali i u drugim zakonodavnim tekstovima Europske unije, osobito onima sekundarnog karaktera.

\section{OGRANIČENJA ISTRAŽIVANJA}

Kao što je u uvodnom dijelu rada naglašeno, rezultati istraživanja odnose se samo na ograničeni korpus Amsterdamskog ugovora kao jedan od tekstova primarnoga prava Europske unije. Stoga intencija autorica i nije bila rezultate dobivene analizom lingvističkih obilježja ovoga ugovornog teksta smatrati relevantnim za sve pravne tekstove EU-a. Ti rezultati mogu biti indikativni za ugovore kao specifičnu vrstu pravnih tekstova EU-a, no pouzdaniji bi se podatci dobili kada bi se analizi podvrgli i drugi opsežniji osnivački ugovori. Kako bi se došlo do egzaktnijih i znanstveno pouzdanijih spoznaja o jezičnim obilježjima karakterističnim za tekstove primarnoga prava EU-a, bilo bi potrebno lingvističkoj analizi podvrgnuti recentniji i opsežniji pravni tekst slične vrste, koji je značajan i relevantan i prema svojemu pravnom karakteru i dometu, poput Ugovora iz Lisabona (2009.). Dobiveni rezultati potvrdili bi ili osporili vjerodostojnost podataka koji su proizašli iz lingvističke analize provedene u ovom radu. Ovo istraživanje, iako ograničeno u svojemu opsegu i domeni, otvara mogućnost opsežnijih istraživanja, kojima bi se onda ostvarili i relevantniji i pouzdaniji rezultati. Istraživanjem širega korpusa, koji bi obuhvaćao različite tekstne vrste u okviru prava EU-a, doznali bismo rabe li se obilježja koja su ovdje utvrđena kao karakteristična za stil Amsterdamskog ugovora i u drugim pravnim tekstovima EU-a te jesu li karakteristična i za jezik prava EU-a općenito. Ovo istraživanje također otvara pitanje karakterističnih obilježja jezika prava EU-a i u drugim jezicima, osobito engleskom i francuskom, kao radnim jezicima u institucijama EU-a.

\section{LITERATURA}

1. Arntz, R.; Sandrini, P., Präzision versus Vagheit: Das Dilemma der Rechtssprache im Lichte von Rechtsvergleich und Sprachvergleich, u: Bassey E. A. (ur): Indeterminacy in

2. Terminology and LSP, John Benjamins Publishing Company, Amsterdam/Philadephia, 2007., str. 135.-157.

3. Busse, D., Recht als Text. Linguistische Untersuchungen zur Arbeit mit Sprache in einer gesellschaftlichen Institution. Reihe Germanistische Linguistik, Tübingen, 1992.

4. Felder, E., Juristische Textarbeit im Spiegel der Öffentlichkeit, Walter de Gruyter, Berlin. New York, 2003.

5. Gardner, J., Misused English words and expressions in EU publications. European Court of Auditors, 2016.

6. Günther, L., Recht und Sprache. Ein Beitrag zum Thema vom Juristendeutsch, Karl Heymanns Verlag, Berlin, 1898.

7. Hassemer, W., Richtiges Recht durch richtiges Sprechen, u: Grewendorf, G. (ur.), Rechtskultur als Sprachkultur - Zur forensischen Funktion der Sprachanalyse, Suhrkamp, Frankfurt am Main, 
1992., str. 71.-92.

8. Karabalić, V., Deutsche Fachsprachen. Ein Lehrbuch, Filozofski fakultet, Osijek, 2018.

9. Klein, J., Parlamentarischer Diskurs als Schnittstelle zwischen politischer Allgemeinsprache und Rechtssprache, u: Haß-Zumkehr, U. (ur), Sprache und Recht, Institut für Deutsche Sprache, W. de Gruyter, Berlin-New York, 2001., str. 163.-180.

10. Kordić, Lj., Njemački jezik prava s povijesnog gledišta, u: V. Karabalić - M. Omazić (ur.): Istraživanja, izazovi i promjene u teoriji i praksi prevođenja, Sveučilište J. J. Strossmayera i Filozofski fakultet, Osijek, 2008., str. 289.-303.

11. Kordić, Lj., Elementi neformalnosti i poetičnosti u jeziku prava, u: Zbornik radova HDPL: Prostor i vrijeme u jeziku: Jezik u prostoru i vremenu, HDPL i Filozofski fakultet Sveučilišta J. J. Strossmayera., Zagreb - Osijek, 2010., str. 175.-185.

12. Kordić, Lj., Kurzwortbildungen als Merkmal der deutschen Rechtssprache, Linguistica, 2013., 53 (2), str. 185.-197.

13. Kordić, Lj., Pravna lingvistika - sinergija jezika i prava, Pravni fakultet, Osijek, 2015.

14. Kordić, Lj.; Marušić, B. (2017): Funktionsverbgefüge (FVG) als Merkmal der deutschen Rechts-und Verwaltungssprache. Comparative Legilinguistics, vol. 29/2017., str. 10.-30.

15. Kühn, P., Juristische Fachtexte, u: Helbig et al. (ur.): Deutsch als Fremdsprache. Ein internationales Handbuch, W. de Gruyter, Berlin-New York, 2001., str. 582.-594.

16. Matilla, H., Comparative Legal Linguistics. Language of law, Latin and modern lingua franca, Ashgate Publishing Ltd., Farnham, 2006.

17. Petrović, V., Syntax des zusammengesetzten Satzes im Deutschen, Školska knjiga, Zagreb, 2001.

18. Sandrini, P., Terminologiearbeit im Recht, International Network for Terminology, Wien, 1996.

19. Sandrini, P., Translation zwischen Kultur und Kommunikation: der Sonderfall Recht, u: Sandrini, P. (ur.): Übersetzen von Rechtstexten - Fachkommunikation im Spannungsfeld zwischen Rechtsordnung und Sprache, Gunter Narr Verlag, Tübingen,1999., str. 10.-45.

20. Sandrini, P., Der transkulturelle Vergleich von Rechtsbegriffen, u: Šarčević, S. (ur): Legal Language in Action: Translation, Terminology, Drafting and Procedural Issues, Globus, Zagreb, 2009., str. 151.-167.

21. Sosoni, V.; Biel, Ł., EU Legal Culture and Translation, International Journal of Language and Law, 7/2018., str. 1.-7.

22. Stolze, R., Die Fachübersetzung - Eine Einführung, Gunter Narr, Tübingen, 1999.

23. Stolze, R., Fachübersetzen - Ein Lehrbuch für Theorie und Praxis, Frank \& Timme, Berlin, 2009.

24. Stolze, R., The Translator's Approach - Introduction to Translational Hermeneutics: Theory and Examples from Practice, Frank \& Timme, Berlin, 2011.

25. Šarčević, S., New Approach to Legal Translation, Kluwer Law International, The Hague-London-Boston, 2000.

26. Šarčević, S. (ur.), Legal Language in Action: Translation, Terminology, Drafting and Procedural Issues, Globus, Zagreb, 2009.

27. Trosborg, A., Translating Hybrid Political Texts u: Trosborg, A. (ed.), Text Typology and Translation, John Benjamins, Amsterdam, Philadelphia, 1997., str. 145.-158.

28. Weber, S., Sprache und Recht, Universität Chemnitz, Chemnitz, 1975. 
29. Yankova, D., On Some Aspects of Prescriptive Legal Texts in Continental, Common Law and Supranational Jurisdictions, u: Sočanac, L.; Goddard, C.; Kremer, L. (ur.), Curriculum, Multinlingualism and the Law. Language and Law - Studies in Legal Linguistics, Nakladni zavod Globus, Zagreb, 2008. str. 483. -495 .

\section{MREŽNI IZVORI}

1. Vertrag von Amsterdam, 1999. http://www.europarl.europa.eu/topics/treaty/pdf/amst-de.pdf. Pristupljeno 11. siječnja 2019.; 14. siječnja 2019.

2. http://morphadorner.northwestern.edu/morphadorner/. Pristupljeno 11. siječnja 2019.; 26. travnja 2019.

3. https://eur-lex.europa.eu/legal-content/HR/LSU/?uri=CELEX:52012SC0093. Pristupljeno 19. lipnja 2019. 


\section{LINGUISTIC FEATURES OF GERMAN LANGUAGE IN THE CONTEXT OF EU-LAW: THE EXAMPLE OF THE TREATY OF AMSTERDAM}

\section{Summary}

This paper aims at exploring linguistic features of the German language of law within the supranational legal system of the European Union. In the theoretical part of the paper, linguistic features of the German language of law are presented and analysed based on the prior research of legal texts in the German language. In the empirical part of the paper, linguistic features of the German language are analysed on the corpus of the Amsterdam Treaty with reference to the categorisation of linguistic features established in the theoretical part. The results of the analysis should indicate which linguistic features are specific for the Treaty of Amsterdam as an example of founding treaties of the European Union and to which extent they differ from general features of the German language of law. Qualitative and quantitative methods are applied in the analysis of excerpted examples at relevant linguistic levels. Based on the fact that different legal systems generate different legal concepts as well as specific legal terminology and phraseology, the hypothesis of this paper is that in the text of the Treaty of Amsterdam, as one of the primary sources of the EU law, the most striking differences shall be discovered in the field of terminology and phraseology, i.e. at the levels of morphology, lexicology and style.

Keywords: $\quad$ EU law, linguistic features, primary sources, German language, The Treaty of Amsterdam

\section{(c) (1) (9)}

This work is licensed under a Creative Commons

Attribution-NonCommercial 4.0 International License.

* Ljubica Kordić, PhD, Associate Professor, Faculty of Law, University of Josip Juraj Strossmayer in Osijek, Stjepana Radića 13, 31000 Osijek, Republic of Croatia, Email address: kljubica@pravos.hr. ORCID: http://orcid.org/0000-0002-2900-7906.

** Zdenka Barna, mag. inf. et comm. et mag. philol. germ., Ivana Gundulića 14, 31400 Đakovo, Republic of Croatia. Email address: zbarna25@gmail.com. ORCID: http://orcid org/0000-0001-6511-068X. 